\title{
PAX5 Gene Mutation
}

National Cancer Institute

\section{Source}

National Cancer Institute. PAX5 Gene Mutation. NCI Thesaurus. Code C158139.

A change in the nucleotide sequence of the PAX5 gene. 